\title{
Civil-Military Relations in Azerbaijan: The Challenges of Wartime Conditions
}

\author{
By Jasur Sumerinli*
}

\section{Introduction}

This article is an attempt to offer a systematic view of the course of the reforms that have taken place in the Azerbaijani armed forces, with a particular focus on relations between the army and society. Since Azerbaijan gained independence in 1991, relations between the Azerbaijani armed forces and society can be divided into four periods, which will be outlined below.

\section{Patriotic Society (1991-94)}

This initial post-independence phase was a period of intense hostilities between Azerbaijan and Armenia. During this time, the existence of active military conflict between the two nations combined with the fact that the attention of the Azerbaijani public was focused on the hostilities forced the public and the mass media to take a patriotic stance, turn a blind eye to internal social problems, and promote the power of the Azerbaijani armed forces. This period saw numerous problems in the armed forces and in supplying and organizing the army. However, the media clearly had no intention of calling attention to these problems, and they made no effort to gather any information regarding these issues. In addition, there was almost no pressure placed on the military by the main ministries within the Azerbaijani government. Attention was drawn to problems within the army when some territory was lost or military operations were unsuccessful, but they did not receive particularly thorough coverage.

\footnotetext{
* Memmedov (Sumerinli) Jasur Mazahir is co-founder of The Center of Military Analytical Studies (HATM); director of information department www.analitika.az; editor-in-chief of the first indepenedent military news agency in South Caucasus MilAz www.milaz.info; responsible editor of supplement "Army Mirror" supported by NATO PDD published in "Ayna" and "Zerkalo" newspapers www.ayna.az and www.zerkalo.az and chairman of "Doctrine" Centre of Journalists Military Research" Public Union.
} 
Azerbaijan's first Minister of Defense, General Valeh Barshatli, had initiated some reforms in the army. He created the system of the army's staff structure and first brigades, and began the process of forming a national staff for the military forces. In short, this period was characterized by the following traits:

- The military forces were a leading power structure in Azerbaijan

- For the first time, defense expenses, the individual components of these expenses, transparency, and the defense planning process became subjects of discussion

- The first steps in the process of modernizing the armed forces were made in Azerbaijan, with improvements in weapons and techniques, and the upgrading of the army's armored cars

- Azerbaijan began choosing strategic allies and establishing priorities for national security.

\section{The "Cease-Fire" Between the Army and Society (1994-98)}

This period began after Azerbaijan and Armenia signed a cease-fire agreement in 1994. This second phase, which lasted until 1998, was one of relative inactivity in relations between the army and society. The biggest problem of this period was that there were no mechanisms in place to aid in the establishment of civil-military relations. In other words, the main government ministries involved in security and defense had difficulty defining what information or activities should be brought to public attention. It was believed that any information or misinterpretation could lead to a new outbreak of armed conflict. During that period, the media was going to great lengths to obtain information, draw attention to problems in the army, and analyze them. Military approaches typical of the old Soviet period were no longer accepted by society, while articles written according to modern standards were met with indignation by the military elite. Therefore, the years 1994-98 can be described as a "cease-fire period" between the army and the public in Azerbaijan. During this period, there was a strong belief that hostilities would resume, and the Azerbaijani army would retake the occupied territories. Therefore, everyone was waiting, and most elements of civil society preferred not to stress the problems in the army. ${ }^{1}$

\footnotetext{
Doktrina Military Research Center for Journalists, “The Relationship Between Media and Power Structures: The Responsibility of the Ministry of Defense," 29 September 2009; available at http://www.milaz.info/news.php?id=7157.
} 
To conclude, this period was marked by the following characteristics:

- Azerbaijan gained time to consider the present state of its armed forces and plan for their future

- Staff structures in the armed forces began to improve, and the system of united command was created in the army

- The heads of the primary power structures began to build connections with the broader society on military issues

- Civil society developed a healthy interest in the problems within the military and in potential ways to solve them.

\section{The "Problem Boom" (1998-2005)}

After the danger of the resumption of hostilities between Azerbaijan and Armenia disappeared, in 1998 several soldiers and officers serving in the army for the first time began appearing in the media to inform society about problems in the army, and provided a list of servicemen who had died of various diseases. During this era, various newspapers and TV channels reported on numerous problems in the army, including shortages of supplies in the field and abuses of power by army officials. Military non-governmental organizations grew much more active, and held numerous news conferences. It was in this period that the Azerbaijani ministries responsible for defense began to sense that they were under close scrutiny by society and the media that represented them.

During this period, a great number of top officers who used to serve in the army told the media about problems in the military without hesitation. Several government ministries, especially the Ministry of Defense, filed numerous law suits against the media, and many journalists were unofficially declared "enemies of the army."2

But despite all this, in 1998-2005 the media managed to turn into a real mediator between the army and civil society in Azerbaijan. Subsequently, this would give the Azerbaijani media a chance to monitor the reforms being carried out in the army. This was a period when the media had a genuine opportunity to investigate what information they could obtain about the military. In sum, then, during this period:

- Some military officers had begun to communicate with civil society about problems within the military

- The Ministry of Defense took a strongly adversarial stance against the media

- Several journalists were unofficially declared "enemies of the army"

- Mechanisms of future cooperation between the military and civilians began to be created.

2 Hasan Aqacan, "Please Clap, Misters," Express (11 December 2007); available at http:// www.milaz.info/news.php?id=657. 


\section{International Support for Improved Civil-Military Relations (2005-present)}

After Azerbaijan and NATO signed the Individual Partnership Action Plan (IPAP) in May 2005, Azerbaijani society's objectives concerning defense and security took on specific outlines, which had never before been the case. In various media outlets, citizens talked about what NATO would like to see in the Azerbaijani army. Within the framework of IPAP, Azerbaijan undertook numerous obligations. ${ }^{3}$ These obligations even contain provisions referring to relations between society and the ministries involved in defense and security - for example, there are IPAP provisions under which the media and society are to be constantly informed about reforms being carried out in the army. Of course, these provisions helped the Azerbaijani media, and it has been evident that since 2005 the relevant Azerbaijani ministries have slightly changed their approach toward relations with civil society, falling more in line with modern requirements.

Since 2005, the Azerbaijani public has gained access to alternative sources of information about the country's defense and security. Citizens now have the opportunity to obtain information about military reforms not just from the respective ministries or from current or former military officers, but also from NATO representatives and foreign experts who constantly visit the country. During this period, the ministries involved in defense have been forced to react not just to journalists' reports, but also to comments by NATO officials and numerous foreign experts on Azerbaijan's defense and security. As a result, a significant information base was created that enabled journalists to analyze developments in the military. ${ }^{4}$

Of course, there are still significant problems in this field: the IPAP document itself has still not been fully revealed to the Azerbaijani public, and the reforms prescribed in this document have not been officially or fully disclosed to the Azerbaijani media. This is regarded as one of the main obstacles to military transparency in Azerbaijan.

Government officials say that the chances of strengthening civil-military relations are improving, and that new methods of implementing mechanisms of public control over the armed forces are currently under consideration.

Public opinion deems it necessary to investigate negative incidents in the armed forces, and to ensure that the military leadership does so in a transparent manner. It is necessary to ensure that civilian government agencies,

3 Robert Simmons, "NATO Supports the Reform, interview with Hafta-ichi (7 November 2008); available at http://www.hafta-ichi.com/newv/2008/11/07/read=22653.

4 Jasur Sumerinli, Ahead, Toward NATO (Baku: Abilov, Zeynalov and Sons, 2007), 5-88; and Sumerinli, "Azerbaijan's Political and Military Obligations in the Relationship with NATO," Media Forum (15 September 2006); available at http://mediaforum.az/articles. php?article_id=20060915015832785\&page $=05 \&$ lang $=$ az\&eu $=0$. 
non-governmental organizations, and representatives of the public can freely intervene in the process. And it is important to announce the results of any investigation into problems in the military and disclose improper relations in the army, the impact on military personnel, and their implications for society. The main purpose of increasing transparency in investigations of problems within the military is to raise the level of interest and investment on the part of the public in solving such problems. It is important to ensure continued productive interaction between civilian and military organizations, the transparency of law-enforcement agencies to the broader society, and the accountability of defense organizations to civilian organizations.

Reforms in the Azerbaijani military have been based on a range of cooperation documents signed between NATO and Azerbaijan since 2005. The information that has been acquired shows that IPAP reflects numerous obligations and intentions in the field of military reforms. According to official information from the Ministry of Defense, Azerbaijan's IPAP covers the development of strategic documents, ensuring the correspondence of Azerbaijan's military education system to NATO standards, the development of relevant documents and training of personnel on transparent budget planning, preparation of one mobile unit, development of a National PfP Training Center for the armed forces, modernization of naval vessels, upgrading one airbase and the NCO academy according to NATO standards, establishment of a simulation and modeling center, and other areas as well. ${ }^{5}$

According to official information, the Azerbaijani Defense Ministry and NATO are involved in the following areas of cooperation:

- Azerbaijan has joined NATO's military training and education program, participating in a new module for the improvement of special programs for sergeants and low-ranking officers in the armed forces and for the preparation of militarystrategic documents in the educational program of Azerbaijan's military academies. It is important to note that the standards of NATO's military education system have been applied in the Azerbaijan Higher Military Academy since 1997, in the War College of the Armed Forces since 2000, and in the Education and Training Center of the Armed Forces since 2001. Annually, academic courses in strategic research and defense management are conducted in the War College of the Armed Forces, with a duration of five months. Senior representatives from other ministries and agencies attend this course. The process of bringing the NCO Academy and training area in line with NATO standards continues. Two NCO instructors from U.S. European Command have been stationed at the Garaheybat Training Center since March 2008 in order to help shape the curriculum at the NCO Academy. Azerbaijani NCO instructors have received training in the United

Doktrina Center, "Preparing Military Bases in Azerbaijan for NATO Exercises," (17 April 2010); available at http://www.ayna.az/2010-04-17/ordunun-aynasi/2401-MudafieNazirliyi-telim-islahat. 
States, Turkey, Germany, and Latvia to gain experience in the relevant academies of these nations. U.S. experts aided in upgrading the firing range, and laser and computerized firing ranges were established at the Education and Training Center and the NCO Academy. ${ }^{6}$

- Peacekeeping and special forces (medical, engineering, and logistics units) are being prepared to participate in international peacekeeping and humanitarian operations. Annually, more than 1000 representatives of the Ministry of Defense attend 10-150 events considered within the Individual Partnership Program (IPP). Areas of emphasis within the implementation of this program include defense policy and strategy; language training; military exercises and related training; military education; training and doctrine; logistics; planning and operational aspects of peacekeeping and crowd control; laws of armed conflict; defense planning; budgeting; and resource management. In 2009, representatives from Azerbaijan participated in 111 IPP events. For 2010, the number increased to 120 events, including fifty training courses; four exercises; eleven seminars; five working group meetings; fourteen conferences connected with exercises; and sixteen other events. Among these events, nine activities were planned to be conducted in Azerbaijan. In order to gain work experience in multinational NATO headquarters, officers of the Azerbaijani military serve at the International Military Staff (Brussels) and at the Joint Force Command HQs (Italy and Netherlands). ${ }^{7}$ Taking into account the expanded level of cooperation with NATO, at present there exist an International Cooperation Department and a Euro-Atlantic Integration Department that are responsible for coordinating the actions of the Ministry of Defense (MoD) with NATO, the Committee on NATO STANAGs, the National PfP Training Center within the Education and Training Center of the Armed Forces, and the NATO/PfP Department at the Military Academy, which functions within the Azerbaijani MoD.

- Training bases are being prepared on the Azerbaijani territory to plan and hold multinational exercises, with crucial assistance from NATO member countriesespecially the U.S., Turkey, Germany, and the U.K. A Simulation and Modeling Center was established within the War College and was equipped with new software, and training courses up to the brigade level are constantly being conducted in this institution. This center is intensively used by NATO militaries to realize various exercises. Of particular note is the Joint Multinational Field Exercise (in

6 Speech by Colonel Vidadi Asgerov, Ministry of Defense of Azerbaijan, at a May 2009 conference in Baku dedicated to the fifteenth anniversary of the relationship between Azerbaijan and NATO.

7 Ibid. 
the spirit of the Partnership for Peace) that is organized within IPAP every year, which was conducted successfully in Azerbaijan.

- The international headquarters of NATO have organized a working meeting at the tactical and operational levels on the subject of assistance for military training and education in the armed forces. To date, Azerbaijan's military is staffed with personnel trained in accordance with NATO standards in national military educational institutions. In addition, up to 200 servicemen are trained annually in military educational institutions overseas, in Turkey, the U.S., Germany, the U.K., Italy, Romania, Hungary, Bulgaria, Latvia, Lithuania, Estonia, and other nations. At the same time, up to thirty foreign servicemen are being trained in military educational institutions in Azerbaijan. ${ }^{8}$

- Azerbaijan is honoring its IPAP obligations to modernize its armed forces and boost their military capability. Operation plans, documentation, maps, and terminology used in command post and field exercises are being applied according to NATO standards.

- The staff structure of all types of troops in the armed forces has been brought into line with NATO standards, and reforms are continuing to convert the Ministry of Defense and the general staff to NATO standards (both joint and general staff).

- Work is continuing within the framework of the Operational Capabilities Concept (OCC) program to achieve operational compatibility with NATO forces. In order to directly participate in NATO-led operations, the Republic of Azerbaijan joined NATO's Operational Capability Concept Evaluation \& Feedback program in March 2004, and dedicated one infantry company to NATO's pool of forces. A mobile battalion was established within one of the brigades, and the Azerbaijani OCC Company is within this battalion. Training of this unit in accordance with NATO standards is currently under way. ${ }^{9}$

- Azerbaijani peacekeeping forces have participated in operations by NATO's International Security Assistance Force (ISAF) in Afghanistan. Additional support was given to this country in the medical sphere and in clearing land mines, and opportunities were created for the Afghan military to study and train

8 Annual Report of the Ministry of Defense of the Republic of Azerbaijan (Baku: Ministry of Defense, January 2010).

9 Speech by Colonel Vidadi Asgerov, Ministry of Defense of Azerbaijan, at a May 2009 conference in Baku dedicated to the fifteenth anniversary of the relationship between Azerbaijan and NATO. 
in Azerbaijan's military schools. A peacekeeping platoon was established within Azerbaijan's armed forces in 1997, and a peacekeeping battalion was established in 2001. The Azerbaijani peacekeeping platoon participated in peacekeeping and peace support operations in Kosovo from September 1999 until 2008. A largescale peacekeeping contingent from the Azerbaijani military served in Iraq from August 2003 until December 2008 as part of the International Coalition Forces. Azerbaijan's peacekeeping platoon has been deployed to Afghanistan under the rubric of ISAF since November 2002. In January 2008, the size of Azerbaijan's peacekeeping contingent in Afghanistan was increased to forty-five men; in February 2009 , this number doubled.

- NATO provided support for the process of preparing key national strategic documents, such as the National Security Concept (NSC), Military Doctrine (MD), and Strategic Defense Review (SDR). The NSC was confirmed by the President of Azerbaijan on 23 May 2007. The Military Doctrine was received by the Parliament of Azerbaijan in June 2010. Today, NATO experts - especially those from the U.S., Germany, and Turkey - are working with their Azerbaijani colleagues in preparing the SDR. According to official information, this key document will be ready at the beginning of 2012 .

At the same time as the level of cooperation between Azerbaijan and NATO has been intensifying, however, a good deal of work remains to be done. According to the Azerbaijani government, thirty-two of the Partnership Goals out of the thirty-eight that were accepted by the Republic of Azerbaijan within the Planning and Review Process (PARP) belong to the armed forces. In order to contribute to NATO-led peace support operations, Azerbaijan formed the following units under the rubric of PARP: a peacekeeping unit; a medical platoon; an engineering platoon; and a helicopter team, with two MI-8 helicopters.

Officials in Azerbaijan's Ministry of Defense agree on the importance of pursuing continued cooperation with NATO. For their opinion, as a result of the past sixteen years of cooperation between Azerbaijani defense structures and NATO, the following things have been achieved:

- Close cooperation with Euro-Atlantic security institutions

- Contributions to international peace and security by participating in peace support operations

- Increased level of operational interoperability within the NATO Operational Capability Concept Evaluation and Feedback program

- Application of NATO standards in the Azerbaijani military

- Enhancement of Azerbaijan's military education and training system 
- Development of strategic conceptual documents

- Training of professional personnel in fields relevant to cooperation

- Improved operational capability.

What currently is Azerbaijan's Ministry of Defense currently planning? According to official information, in order to improve the defense capability of the armed forces the MoD will further continue its activities based on mutual cooperation. In this regard, the MoD has set the following priorities:

- Continue to improve the operational readiness of Azerbaijan's peacekeeping and other units in order to contribute to NATO-led peace support and humanitarian aid operations

- Implement commitments derived from NATO's IPAP and PARP objectives in order to modernize the armed forces of the Republic of Azerbaijan according to its strategic interests

- Continue reforms related to the introduction of NATO standards in the armed forces

- Continue cooperation within the Operational Capability Concept Evaluation and Feedback program in order to increase interoperability with NATO forces. ${ }^{10}$

\section{Challenges in the Reform Process}

However, studies show that serious problems have cropped up in the implementation of numerous reforms planned in the first (2006-07) and second (2008-10) stages of IPAP. First, there has been no progress in implementing civilian control over the armed forces. Military spending and the budget are not transparent, and the main defense-related ministries do not report to parliament. Second, there have not been sufficient improvements in the administrative system of the defense ministry staff ( both military and civilian). The current command staff and command control procedures have not been examined and evaluated. Third, the process of separating the general staff of the armed forces from the defense ministry has actually failed. Attempts have been made to mix the J (Joint) and $\mathrm{G}$ (General) systems, which has led to inefficiency in the reform process.

Annual Report of the Ministry of Defense of the Republic of Azerbaijan (Baku: Ministry of Defense, January 2010). 
Fourth, a number of changes that actually did take place as a result of the reforms have not been reflected in the country's military legislation. Fifth, human rights problems are on the rise in the Azerbaijani armed forces. The material and technical support of the armed forces is at a low level, and the rights of military staff to livable housing are being violated.

A sixth area of concern - and one of the most significant-is that access to the process of drafting and adopting conceptual documents has been extremely limited. Various groups of Azerbaijani civil society, including NGOs and representatives from the media, did not participate in the development of Azerbaijan's Military Doctrine and National Security Concept. For this reason, there is a perception in Azerbaijani society that contents of these documents are temporary. One aspect of the drafting process was quite obvious to outside observers: the fact that there are significant areas of difference between the Military Doctrine and the National Security Concept. The NSC was adopted before the Russian-Georgian war of August 2008, while the Military Doctrine was drafted after that conflict. While the NSC places a priority on achieving integration into Euro-Atlantic security structures, the Military Doctrine reflects a shift in orientation toward a more "balanced" policy on the part of the Republic of Azerbaijan. The NSC mainly focuses on harmonizing the nation's military with NATO standards in connection with IPAP and other documents. But the Military Doctrine declares that Azerbaijan prefers to create an army based on mixed standards-on historical tradition and modern experience, not relying solely only on NATO standards.

The final and most pressing concern is that Azerbaijani society is in the dark about the program of reforms in the armed forces. Azerbaijan-NATO cooperation documents and the text of the IPAP have still not been freely circulated. This level of secrecy makes it very difficult for civil society to support reforms within the military (since they do not know what the reforms are), and it keeps NGOs from having full awareness of the scope of the projects that are under way to face modern challenges in the sector of military and defense. ${ }^{11}$

As was mentioned above, thirty-two of the thirty-eight partnership goals adopted by Azerbaijan within the framework of PARP are related to the armed forces. But only twelve of them have been implemented so far, while work is continuing to achieve other Partnership goals. ${ }^{12}$

11 The Center for Military Analytical Studies, "No Realized Reforms," Ayna (10 April 2010); available at http://www.ayna.az/2010-04-10/ordunun-aynasi/2350-IPAP-Azerbaycan-islahatlar.

12 Annual Report of the Ministry of Defense of the Republic of Azerbaijan (Baku: Ministry of Defense, January 2010). 
THE QuARTERLY Journal

\section{Democratic Control of the Military}

It should be noted that the reforms carried out in the first and second stages of IPAP relate to the transparency of the defense budget and issues of civilian democratic control over the military. In fact, these issues should together be regarded as the cornerstone of the reform process. According to the information available, one of the tasks set forth under IPAP is implementing structural changes in the MoD, increasing the involvement of civilians in the defense ministry apparatus, identifying posts that can be occupied by civilian staff, and codifying the necessary changes and addenda to legislation related to the defense system in order to ensure that these changes remain in place. However, studies show that Azerbaijan is in no hurry to honor its obligations in this regard, or to appoint civilians to leadership positions in the defense ministry. The stated reason for this delay is the fact that the country is at war with Armenia. However, it is impossible to regard this as a strong argument. ${ }^{13}$

In fact, when we say "democratic control," it is not enough for only the defense minister and some military officials to be civilians. One of the obligations reflected in IPAP and other cooperation documents relates to the need to use a mechanism of parliamentary control over the armed forces, to bring military legislative documents in line with NATO standards, and to make legislative power more active in this area. There are serious problems in this regard in Azerbaijan. First and foremost, the mechanism of the relevant ministries' accountability to parliament is still not clear. At the same time, the parliamentary security and defense committee has limited scope to intervene in the process of building the military or to oversee the reforms envisaged by IPAP. This manifests itself both in terms of the committee's legal authority and in terms of the knowledge and experience of the MPs that make up the committee.

Specifically, there are serious problems related to the staff of the Azerbaijani armed forces. It should be borne in mind that NATO-educated officers are being promoted very slowly in Azerbaijan. There are significant obstacles to this process. Therefore, there are serious doubts as to whether the process of reforms will be completed successfully, since most of the officers holding top positions in the military are still Soviet-educated. Although Azerbaijan has joined NATO's program for military training and education in the armed forces, no significant reforms are being carried out in this field.

Araz Azimov, Deputy Foreign Minister of Azerbaijan, APA (7 December 2009); available at http://az.apa.az/news.php?id=170994. 


\section{Military Staff Structures}

In the middle of 2009, a number of staff and structural reforms were carried out in the central apparatus of the defense ministry and in the general staff of the armed forces, and new departments were set up. However, these reforms did not result in the implementation of the main goals reflected in IPAP: the defense ministry and the general staff were not separated, and the defense ministry unit engaged in strategic planning was not staffed with civilians. The most significant contradiction relates to the compliance of reforms in the upper echelons of the army with the joint and general staff systems. Statements by MoD officials show that, although Azerbaijan initially agreed to use the joint system in the army, it decided later that the use of a mixed joint and general system was more expedient. Studies show that this part of the reform process is not being implemented on the basis of the provisions reflected in IPAP. What is striking here is that the defense minister in Azerbaijan still dominates the general staff, and it is possible that people who hold top positions in law enforcement are creating obstacles to reforms in this field. ${ }^{14}$

Another problem is that the reforms carried out in the armed forces under the framework of IPAP have no legislative basis. For example, the changes that have occurred as a result of the reforms are not reflected in the country's military legislation. Specifically, there are no clear outlines as to the functions of staff in the new system in the army, the period of service in each post, and the duration for which a rank is held before retirement. For example, the MoD itself still has no statute, and no changes have been made to the law in connection with the latest staff and structural changes in the military. In general, neither the law on the armed forces nor other sets of regulations related to the military have undergone any serious changes. On the whole, most of the legislative acts, statutes, and regulations covering the activities of the armed forces are left over from the Soviet period, and the process of bringing the Azerbaijani military into line with NATO standards has been fraught with contradictions.

\section{Conclusion}

Although Azerbaijan has work to do to meet its side of its cooperation agreements with NATO, it does not operate in a vacuum. The events that took place in the South Caucasus in 2008 and the geopolitical struggle in the region affect Azerbaijan-NATO relations as well, and it should be noted that some of Azerbaijan's neighbors (most

14 Doktrina Military Research Center for Journalists, "Serious Changes are Expected in Azerbaijan's MoD and Military Headquarters," Bizim Yol (15 October 2008); available at http://bizimyol.az/index.php?mod=news\&act=view\&nid=16331. 
notably, Russia) are opposed to close cooperation between Azerbaijan and the Alliance. In our view, NATO should take these realities into account, and support for Azerbaijan's defense and security sectors should be increased. This support should cover a number of areas: legislation, supplies, and the updating of weapons and military hardware. NATO should increase its expert support for Azerbaijan in military reforms, especially in terms of military legislation. Servicemen should be given material support, and their rights should be protected.

One of the biggest problems facing post-Soviet countries in adopting NATO standards relates to the issue of weapons and military hardware. Since the weapons, munitions, and military hardware used by the Azerbaijani armed forces are of Russian origin, there is clearly a serious dependence on Russia in other military areas. For this reason, NATO should carry out specific work to involve countries like Azerbaijan, which are spending vas sums on armaments, in a preferential arms and military hardware market.

At the same time, it is possible that individual officials are creating obstacles to the implementation of NATO standards in the Azerbaijani armed forces, and therefore I believe that the process of adopting NATO standards in Azerbaijan should also involve the general public. This can be done only if the full essence of documents like the Partnership for Peace and IPAP are disclosed to the people. Cooperation will only succeed if it has the full support of Azerbaijani society.

Today it is important to develop a system both in civil society and in government to inform the public about reforms in the armed forces. In this regard, the preparation of clear-cut doctrinal documents that envisage the future development of the armed forces is crucial. It is important to ensure that individuals, especially servicemen, have detailed information about the future of the country's defense and security institutions, and that educational work is carried out in this area.

Although IPAP reflects objectives to develop judicial and public control mechanisms for the armed forces, Azerbaijan has seemed to be in no hurry to take concrete steps in this direction or to support public activities. The task of involving society in defense issues and informing the public about reforms in the army-tasks that were proposed by IPAP — have yet to be implemented. Studies show that, although the ministry of defense has intensified its level of relations with the public (and especially with the media) since 2005, this has not increased public knowledge of what is going on within the military. Although there is information that IPAP contains regarding the obligation to adopt an information strategy for law-enforcement bodies, including the MoD, to increase transparency, these have yet to be honored. 
If we examine the existing situation in Azerbaijan, it emerges that the compliance of our military with the values of a democratic society is far from satisfactory. For example, mechanisms of democratic control over the armed forces barely function in Azerbaijan:

- The ministry of defense and other law-enforcement bodies make no reports to parliament on issues of concern or on the status of reforms

- Military spending is not transparent

- Society is given inadequate information about reforms based on NATO standards in the armed forces

- Azerbaijani citizens are unaware of the specific essence of the cooperation documents the country has signed with NATO

- There has been no serious progress in addressing the social problems of servicemen or their families

- The level of social security provided for servicemen is still low

- Azerbaijani society plays a very passive role in preparing documents related to the country's defense and security.

Studies show that it is necessary to carry out drastic reforms to ensure civilian democratic control over the armed forces in Azerbaijan and to benefit from British, U.S., Georgian, Ukrainian, and Turkish experience in this field. Currently, NGO unions are being set up to ensure public control over the armed forces in Azerbaijan. This process appears to be supported by the country's public and official agencies. But only time will tell if these crucial processes will result in true democratic control over Azerbaijan's armed forces. 
THE QUARTERLY JOURNAL

\section{Bibliography}

Aqacan, Hasan. "Please Clap, Misters." Express (2007).

Sumerinli, Jasur. Ahead, Toward NATO. Baku: Abilov, Zeynalov and Sons, 2007. 